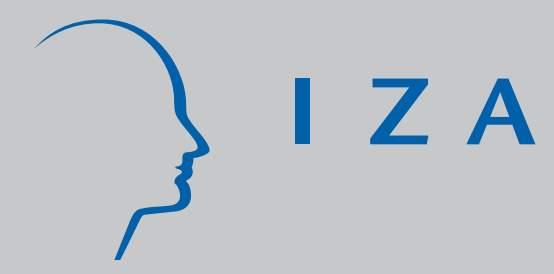

IZA DP No. 1671

\title{
Mbonlighting Behavior over the Business Cycle
}

Catalina Amuedo-Dorantes

J ean Kimmel

J uly 2005 


\title{
Moonlighting Behavior over the Business Cycle
}

\author{
Catalina Amuedo-Dorantes \\ San Diego State University \\ and IZA Bonn \\ Jean Kimmel \\ Western Michigan University \\ and IZA Bonn
}

Discussion Paper No. 1671

July 2005

\author{
IZA \\ P.O. Box 7240 \\ 53072 Bonn \\ Germany \\ Phone: +49-228-3894-0 \\ Fax: +49-228-3894-180 \\ Email: iza@iza.org
}

\begin{abstract}
Any opinions expressed here are those of the author(s) and not those of the institute. Research disseminated by IZA may include views on policy, but the institute itself takes no institutional policy positions.

The Institute for the Study of Labor (IZA) in Bonn is a local and virtual international research center and a place of communication between science, politics and business. IZA is an independent nonprofit company supported by Deutsche Post World Net. The center is associated with the University of Bonn and offers a stimulating research environment through its research networks, research support, and visitors and doctoral programs. IZA engages in (i) original and internationally competitive research in all fields of labor economics, (ii) development of policy concepts, and (iii) dissemination of research results and concepts to the interested public.
\end{abstract}

IZA Discussion Papers often represent preliminary work and are circulated to encourage discussion. Citation of such a paper should account for its provisional character. A revised version may be available directly from the author. 
IZA Discussion Paper No. 1671

July 2005

\section{ABSTRACT}

\section{Moonlighting Behavior over the Business Cycle}

Using data from the 1979 National Longitudinal Survey of Youth, we examine the cyclicality by sex of moonlighting and moonlighting hours. We find that, once we account for the sample selection into employment, both men and women exhibit procyclical moonlighting probabilities. Likewise, moonlighting hours for male multiple job holders are procyclical. These findings contradict the frequent claim that moonlighting increases during economic downturns due to economic hardship. Instead, moonlighting appears responsive to growing employment opportunities during economic expansions. At any rate, the systematic variation of moonlighting over the business cycle may have implications for the procyclical nature of real wages.

JEL Classification: J2

Keywords: moonlighting, multiple job holding, business cycles, U.S.

Corresponding author:

Catalina Amuedo-Dorantes

Department of Economics

San Diego State University

5500 Campanile Drive

San Diego, CA 92182

Email: camuedod@mail.sdsu.edu 


\section{Introduction}

During economic downturns, employment levels fall, unemployment rates increase and, as recent evidence confirms, real wages are somewhat procyclical. Yet, very little is known, even descriptively, about the cyclicality of multiple-job holding. Shown in Figures 1, 2 and 3 are national time-series trends of the aggregate unemployment rate plotted with the female, male and total moonlighting rates. Overall, no consistent cyclical trend can be found, but there is some suggestion of countercyclical male moonlighting during the late 1970s and 1990s. However, from a graphical analysis of national time series moonlighting data during the 1960s and 1970s, Stinson (1987) finds evidence of large increases in moonlighting during expansionary periods despite its non-responsiveness during recessions.

From a practical standpoint, there are numerous reasons to be interested in the cyclicality of second job holding. First, moonlighting has played, and can be expected to continue to play, a visible role in the U.S. workforce. As a reference, the overall moonlighting rate was already 5.2 percent as of 1970, with 7.0 percent of male workers and 2.2 percent of female workers holding multiple jobs. This overall moonlighting rate remained practically unchanged over the course of the next 30 years; yet, its gender incidence fluctuated over this time period. In particular, the female moonlighting rate grew to 3.8 percent in 1980, 5.9 percent in 1991, and exceeded the male rate for the first time in 1995 (6.5 percent versus 6.3 percent). As of the year 2002, the overall moonlighting rate was still similar to the moonlighting rate as of 1970 (i.e. 5.3 percent), although now females were more likely to moonlight than males (5.6 percent versus 5.1 percent). ${ }^{1}$

\footnotetext{
${ }^{1}$ These data were obtained from the Bureau of Labor Statistics, whose researchers compiled the data from the Current Population Survey.
} 
A second motivation for our interest in the cyclicality of moonlighting stems from its potential role on the observed cyclicality of real wages. Until the 1990s, researchers mostly agreed that aggregate real wages were, at best, acyclical. However, as first discussed by Bils (1985), this finding was based on average real wage data possibly affected by the cyclicality in the skill mix of jobs (i.e., the composition of jobs). Using longitudinal data to adjust for this bias, Solon, Barsky and Parker (1994) find that real wages, measured as average wages across all jobs, are slightly procyclical. If the tendency to hold multiple jobs fluctuates in some systematic manner over the business cycle, then this cyclicality of moonlighting could bias the individual average wage measure used by Solon et al. (1994). This bias, in turn, would lead to a misleading conclusion regarding the relative cyclicality of real wages. ${ }^{2}$

Yet a third reason for examining the cyclicality of multiple job holding is based on the importance of moonlighting as a means to facilitate any labor supply adjustments during temporary economic downturns or upturns. ${ }^{3}$ As such, the analysis may help address questions regarding the ability of local labor markets to draw workers into second jobs during expansions or recessions and, through a description of their characteristics, inform the debate on the quality of the jobs being created in such circumstances.

A final policy relevant motivation for this research refers to the structure of job-related taxes affecting secondary jobs given their role during economic fluctuations. In this regard, as explained by Anderson and Meyer (2003), it is worth noting that unemployment insurance

\footnotetext{
${ }^{2}$ Specifically, because second job wages tend, on average, to be lower than primary job wages (see for example Kimmel and Conway (2001)) in the event of procyclicality in moonlighting, as the unemployment rate goes up, moonlighting rates will fall (i.e., fewer secondary job wages will be included in individuals' average hourly wages). Therefore, average real wages will rise due to the declining incidence of second job holding, even ignoring the cyclicality in primary job wages. This would imply that average primary job real wages are more strongly procyclical than found by Solon et al (1994).

${ }^{3}$ Conway and Kimmel (1998) determine that if labor supply elasticity estimates were adjusted to reflect this additional margin of adjustment, then these estimated elasticities would be increased, although the magnitude of increase is small.
} 
payroll taxes are highly regressive, in large part because benefits are structured in the same way. ${ }^{4}$ However, due to the UI payroll tax's low taxable wage base, moonlighters with relatively few hours on the second job still are subject to the full UI tax on that second job, despite likely lacking eligibility for benefits in the event of a layoff. Additionally, the UI tax structure creates a disincentive for employers to create these jobs. Considering the important role that multiple job holding can play in the economy by responding to "just-in-time” labor needs on the part of firms and workers, it is important to gain a better understanding of the cyclical nature of moonlighting, which can help inform the debate on how best structure the UI tax.

Given the magnitude of moonlighting and the potentially crucial policy implications that its cyclicality may have for the functioning of the labor market, we next examine the responsiveness of multiple job holding and hours worked by multiple job holders to business cycles. In particular, we ask ourselves the following questions: Is there evidence of moonlighting cyclicality? Do men and women display differences in their moonlighting cyclicality? What are the practical implications of observed cyclical fluctuations in multiple-job holding? Could moonlighting contribute in any way to the cyclical trends in wages, and if so, what might its role be? The research herein addresses these issues.

\section{Moonlighting and the Business Cycle}

There is often the presumption that moonlighting is countercyclical. In this vein, the Employment Policy Institute (1999) asserted: “The benefits of persistent low unemployment are reflected in many labor market indicators. Multiple job holding, for instance, has fallen over the last year... .” Nonetheless, from a theoretical standpoint, moonlight rates can be procyclical or counter-cyclical. On one hand, from a demand side, moonlighting opportunities may be limited

\footnotetext{
${ }^{4}$ The authors find that the lowest decile workers pay nearly 3\% of the earnings in UI payroll taxes, while the highest decile workers pay approximately $0.5 \%$.
} 
during a recession as the total number of jobs falls. On the other hand, from the supply side, workers may choose to moonlight in an effort to stabilize family income during a downturn of the economy when unemployment rates are high and real wages may fall.

Partridge (2002) examines moonlighting behavior during the years 1994 through 1998 using state-level data. While his focus is on the nature of second job holding during a period of strong economic growth, his paper offers insight into the potential cyclical pattern of moonlighting. If moonlighters face a relatively high likelihood of layoff during periods of high unemployment or if moonlighting rises during periods of rapid economic growth and labor shortages, then moonlighting might be procyclical (pg. 426).

Conway and Kimmel (1998) propose a model that leads to a more rigorous prediction regarding the cyclicality of moonlighting. According to their theoretical framework, hours on the primary job and hours on the secondary job (along with leisure hours) enter the utility function separately. Their model explicitly allows for two distinct reasons for moonlighting: primary job constraints and job heterogeneity (i.e., the second job might provide non-wage remuneration or affect utility differentially from the primary job). From their model, it follows that an increase in non-wage income leads to a decline in moonlighting. As such, moonlighting appears to be countercyclical. Using a fixed effects logit model of moonlighting, Heineck and Schwarze (2004) find support for this notion. ${ }^{5}$

Boheim and Taylor (2004) expand Conway and Kimmel's list of reasons for moonlighting to include two additional motivations for moonlighting, both related to business cycle fluctuations. Their reasons consist of moonlighting in response to negative financial

\footnotetext{
${ }^{5}$ Heineck and Schwarze (2004) fill an important gap in the moonlighting literature with their comparison of secondary job holding in Germany and the United Kingdom. This cross-country comparison permits them to draw conclusions regarding the role that institutions might play in moonlighting outcomes, and they conclude that while institutions matter, they are not a substantial factor.
} 
shocks and moonlighting in response to heightened primary job insecurity. They find some evidence for primary job constraints as a moonlighting motive, weak support for the job insecurity motivation, and mixed evidence of moonlighting in response to financial shocks.

Yet other studies in the literature refer to expectations about future income as another motive for moonlighting. In this vein, Bell, Hartwright and Hart (1997) investigate the possibility that workers might take second jobs as a hedge against future unemployment. That is, as expectations regarding a future economic downturn rise, current moonlighting rates might increase. Their study, using British data from the years 1991 to 1998, fails to yield support for this hypothesis. ${ }^{6}$

In sum, there is sufficient evidence to believe on the existence of moonlighting cyclicality. However, given that men and women exhibit different labor market trajectories, their moonlighting choices and cyclicality may vary as well. Indeed, historically, female moonlighters were more likely to moonlight for immediate financial reasons (see for example Kimmel and Powell, 1999), for primary job constraints (Averett, 2001), or to family responsibilities (Allen 1998). These gender differences in moonlighting patterns have diminished over time. Yet, female moonlighters are still much more likely to package together a full-time primary job with a part-time secondary job, while male moonlighters are more likely to moonlight with two full-time jobs.

In addition to varying multiple job holding motivations, moonlighting cyclicality could vary by sex as a result of gender differences in the demographics of moonlighters. In this regard, male moonlighters are more likely to be married or have children, while the opposite is true for females.

\footnotetext{
${ }^{6}$ British moonlighting differs from U.S. moonlighting in three important ways: Brits have a much higher overall moonlighting rate, more moonlighting persistence over time, and most surprisingly, average secondary job wages are much higher than average primary job wages.
} 
Yet another reason for expecting gender differences in moonlighting cyclicality stems from the occupational segregation by sex and the extent of seasonality at the industry level, which would lead us to expect different moonlighting responses to cyclical fluctuations by gender. In this vein, Goodman (2001) examines the cyclicality of service jobs and notes that service jobs do not suffer much during recessions (although their job growth does wane). To the extent that women are somewhat more likely to work in the service sector, they may exhibit somewhat less cyclicality in their moonlighting behavior than men.

Finally, additional hints regarding potential sex differences in moonlighting behavior over the business cycle can be gleaned from Stinson (1990), who shows that men moonlight during longer periods of time. In what follows, we examine the cyclicality of male and female moonlight rates. First, we describe the data used our analysis. We then discuss our methodology in section IV. Section V contains a discussion of our results and Section VI concludes.

\section{Data and Descriptive Statistics}

We use data drawn from the Geo-coded 1979 National Longitudinal Survey of Youth File (NLSY79 Geo-coded file). ${ }^{7}$ This is a nationally representative sample of 12,686 civilian young men and women aged 14-21 as of December 31, 1978. This cohort was initially interviewed annually from 1979 through 1994. Starting in 1994, the interviews were conducted biennially.

We work with separate unbalanced panels of men and women from the 20 rounds of the NLSY79. ${ }^{8}$ In this last round (corresponding to the year 2002), a total of 8,033 civilian and

\footnotetext{
${ }^{7}$ The NLSY-GeoCoded file data as well as documentation are available at: http://www.bls.gov/nls/nlsgeo97.htm . Per the Geo-coded file contract agreement \#03-77 with the United States Department of Labor, Catalina Amuedo-Dorantes handled all NLSY data analyses and safeguarded all data files. ${ }^{8}$ Hence, we calculate robust standard errors to account for the resulting heteroscedasticity that may affect our estimation.
} 
military respondents were still in the sample. We restrict our sample to person-year observations for which information is available regarding employment, earnings, race, gender, age, education, marital status, fertility, work limitations due to health related reasons and other location specific variables. In particular, we use the week-by-week longitudinal work record on each respondent from January 1978 to the year 2002 to construct variables indicative of the respondent's sector of employment, occupation, tenure, weekly hours worked, and hourly rate of pay at the primary job. ${ }^{9}$ Similarly, we create a dummy variable indicative of whether the respondent moonlighted in the event of holding more than one job simultaneously for longer than one week, ${ }^{10}$ and compute the total number of hours that each respondent moonlighted in the event of multiple-job holding.

Preliminary employment and moonlighting rates for men and women over the last two decades are shown in Table 1. In part due to the aging nature of the NLSY79 cohort, employment and moonlighting rates increased between 1980 and the year 1990. However, they later on decreased from 1990 to the year 2000. In particular, despite averaging 7 percent for both men and women over the period under consideration, moonlighting rates show some cyclicality, with moonlighting rates peaking in the year 1990. These rates are somewhat higher than rates produced by other U.S. data sources because the NLSY79 cohort displays relatively high moonlighting rates.

Tables 2A and 2B further inform on some of the personal characteristics of single and multiple job holders for the years 1980, 1990, and 2000. Once more, some of the differences seen over time reflect simply the aging of the NLSY79 cohort. An increasingly larger fraction of

\footnotetext{
${ }^{9}$ We deflate hourly wages using the CPI for all urban consumers, not seasonally adjusted, with base period 19821984 was retrieved from http://www.bls.gov/cpi/home.htm

${ }^{10}$ In this manner, we avoid counting as moonlighting short transitions from one job to another job consisting of just a few days.
} 
Black men and women work and, in particular, moonlight from 1980 to the year 2000.

Additionally, moonlighters appear to be more highly educated than non-moonlighters, although the education gap narrows from a one year gap in the year 1980 to approximately a half year gap in the year 2000. In terms of family characteristics, married men and women are less likely to hold two jobs and single job holders seem to have more children than their moonlighting counterparts as of 1980. Finally, a higher fraction of moonlighters reside in urban areas relative to single job holders.

Further information regarding the possible cyclicality of moonlighting rates can be gleaned by examining the job status transitions of men and women in this NLSY79 cohort. Job transitions experienced by men and women from unemployment, single job holding, and multiple job holding from year ( $t-1)$ to any of these three work statuses in year $t$ are shown in Tables 3A and 3B. Of particular interest to us are the job transitions of moonlighters. Note that moonlighting is quite persistent, with nearly one half of male and female multiple job holders having moonlighted during the previous year. Therefore, in addition to business cycles, individual heterogeneity may play an important role in explaining moonlighting behavior. ${ }^{11}$ However, it is also worth noting the large fraction of moonlighters who were single job holders (about 46 percent) or even unemployed (about 7 percent) a year earlier relative to the fraction of unemployed individuals or single job holders in period $t$ originating from other work statuses. Finally, there is little evidence of gender differences in terms of job transitions across job statuses.

\footnotetext{
${ }^{11}$ It also would be interesting to examine the cyclicality of moonlighters' job packaging; that is, how moonlighters combine fulltime with part-time jobs and how this packaging cycles.
} 


\section{The Incidence of Moonlighting over the Business Cycle: The Role of Heterogeneity}

A) Methodology

Our purpose is to examine the impact of changes in the unemployment rate on the moonlighting behavior of men and women. We first focus on moonlighting cyclicality by sex and subsequently extend the empirical analysis to examine the choice of moonlighting hours of multiple job holders. Underlying our empirical analyses is a standard individual utilitymaximizing model extended to incorporate hours on the primary job as well as secondary job directly in the utility function. (See Conway and Kimmel, 1998 for a detailed derivation of this theoretical framework and its resulting empirical implications.) This model set-up permits consideration of multiple motives for moonlighting, summarized as primary job constraints and job heterogeneity. Conway and Kimmel (1998) derive their structural disequilibrium model from this framework, but here we rely on a reduced form approach in order to more directly address our primary concern of cyclicality.

The bulk of the literature examining the cyclicality of real wages relies on measures of the national unemployment rate. However, given the variation in regional labor markets in moonlighting rates (Partridge, 2002), we choose a state-level measure of unemployment. ${ }^{12}$ We begin by examining the impact of state unemployment rates on the decision to moonlight by means of a probit model that corrects for heteroskedasticity in the error term using the pooled data from the various waves of the NLSY79 as follows ${ }^{13}$ :

$$
m^{*}=\Lambda\left(\alpha_{1}+\alpha_{2} U+\alpha_{3}^{\prime} X+\alpha_{4} t\right)+\varepsilon, m=1 \text { if } m^{*}>0 \text { and } 0 \text { otherwise, }
$$

\footnotetext{
${ }^{12}$ As explained by Partridge (2002, pg. 431), the ideal unemployment measure would be as specific to the individual as possible. In this spirit, we conduct sensitivity analyses using gender-specific measures of state unemployment rates, but find no difference in our results. Results are available from the authors.

${ }^{13}$ We adjust standard errors for the group-wise heteroskedasticity arising from the fact that state unemployment rates vary only across states while the remaining equation variables vary across individuals (Moulton 1986).
} 
and where $m^{*}$ is the latent variable representing the moonlighting choice of respondents. The

vector $U$ represents the state unemployment rate, $X$ contains information on the personal and job related characteristics of the ith worker at time $t$, and $t$ is a linear time trend. ${ }^{14}$

Note, however, that the estimation of equation (1) ignores any heterogeneity biases that may arise from omitting a time-constant variable, such as the unobserved individual effect.

Given the importance of individual level heterogeneity in employment-related decisions and the likelihood for unobserved individual level characteristics, such as ability, to be correlated with some explanatory variables included $X$, such as educational attainment, we subsequently estimate a fixed-effect logit model of the individual decision to moonlight as follows:

$$
m_{i t}^{*}=\Lambda\left(\alpha_{1}+\alpha_{2} U_{i t}+\alpha_{3}^{\prime} X_{i t}+\alpha_{4} t\right)+v_{i t}, m_{i t}=1 \text { if } m_{i t}^{*}>0 \text { and } 0 \text { otherwise, }
$$

where: $v_{i t}=a_{i}+u_{i t}$, with the unobserved effect $\left(a_{i}\right)$ being uncorrelated with the explanatory

variables $\left(X_{i t}\right)$. Due to the large number of observations lost in the logit fixed-effects estimation as a result of the large number of individuals who never moonlight, we also estimate a feasible GLS or random-effect probit model of the probability of moonlighting. In addition to using a larger sample in the model estimation, the random-effects model offers an important advantage. Through the use of feasible GLS, we are able to correct for biases in the coefficient estimates from regression (2) in the presence of state-year specific errors resulting from having the same unemployment rate for all individuals in that state and particular year. ${ }^{15}$ Additionally,

\footnotetext{
${ }^{14}$ We opted not to include year dummies because, to the extent that our data come from a single cohort of individuals, the population is not likely to have a different distribution over time and, as such, the year dummies would likely be picking up much of the cyclical variation in the unemployment rate that we are interested in. ${ }^{15}$ As noted by Solon, Barsky, and Parker (1994), Shin (1994), Solon, Whatley, and Stevens (1997), Devereux (2001)), and Shin and Solon (2004) it is important to correct standard errors by means of feasible GLS or a two-step regression method. While the two-step procedure is popular when assessing aggregate trends, we opt for the use of a more efficient one-step estimation using feasible GLS examining the impact of unemployment rates on the individual decision to moonlight. By focusing on the individual level decision to moonlight, we can further maintain the exogeneity of the unemployment rate and, as such, the consistency of the estimates.
} 
knowledge of the pooled OLS, the fixed-effects, and the random-effects estimates allows us to gauge the significance of the unobserved individual effects as well as the extent of the inconsistency in the random-effects estimates when the individual effect and some of the regressors are correlated. Specifically, when the pooled OLS and the random-effects are similar, the unobserved effect is relatively unimportant and we can continue to use pooled data techniques. However, if the pooled OLS and the random-effects differ substantially, a further comparison of the random-effects and the fixed-effects estimates reveals the extent of the inconsistency bias affecting the random-effects. In carrying this exercise, it is important to remember that because the pooled OLS and the random-effects models rely on a normal distribution, the magnitude of their estimates is not directly comparable to the size of the coefficients in the fixed-effects model using the logistic distribution. Nevertheless, we can still compare the signs and statistical significance of the coefficient estimates.

\section{B) Results}

The coefficients on the state unemployment rate variables measure the effect that a onepercentage point increase in the unemployment rate has on average male and female moonlighting rates. A negative coefficient would provide evidence of the procyclicality of moonlighting rates, whereas a positive coefficient would be indicative of the counter-cyclical nature of moonlighting rates.

According to the pooled OLS, the fixed effects, and the random effects estimates in models (1) through (3) in Table 4, male moonlighting rates are not significantly altered by the business cycle as captured by the unemployment rate. Furthermore, the similarity of the pooled data probit allowing for clustering at the individual level and the random-effects probit estimates -both of which are negative and statistically not different from zero, suggests the non-crucial 
role played by individual level heterogeneity in shaping the coefficient estimates. In fact, not much difference is found between the fixed-effects and random-effects estimates. The robustness of the results to alternative specifications accounting for individual level heterogeneity is of special interest when it comes to modeling respondents' self-selection into employment and, subsequently, into multiple job holding as we shall discuss in what follows.

In contrast to male moonlighting rates, female moonlighting exhibits a counter-cyclical behavior. That is, moonlighting and unemployment appear positively correlated, implying that moonlighting rises with economic downturns. This would suggest moonlighting occurs in response to the existence or anticipation of economic distress for women. As with men, it is worth noting the similarity of the pooled data probit allowing for clustering at the individual level and the random-effects probit estimates. Both estimates are statistically different from zero, positive, and imply an increase in the moonlighting rate of less than half a percent as the unemployment rate rises by 1 percentage point. In light of the similarity of the pooled OLS and random effects estimates, we next use the pooled sample to explore the role of sample selection into employment in examining the cyclicality of male and female moonlighting rates.

\section{The Incidence of Moonlighting over the Business Cycle: The Role of Self-selection}

\section{A) Methodology}

While the estimation of equation (2) would account for any heterogeneity biases that may arise from omitting a time-constant variable, such as the unobserved individual effect, it would still ignore the ongoing selection into employment and moonlighting. In particular, respondents first have to decide whether to work and, subsequently, whether to moonlight conditional on their current employment. As noted earlier, when the pooled OLS and the random-effects are similar, we can conclude that the unobserved effect is relatively unimportant and, as such, we 
can use pooled data techniques and estimate a bivariate probit with sample selection where respondents first choose whether to work and, subsequently, whether they want to hold multiple jobs. Specifically, we can consider the following two equation system:

$$
\text { Work Selection Rule: } W_{i}=\alpha_{1,0}+\alpha_{1,1} U_{i}+\alpha_{1,2}^{\prime} X_{i}+\alpha_{1,3} t+\alpha_{1,4} Z_{i}+\varepsilon_{1 i}
$$

$$
\text { Multiple Job Holding Equation: } M_{i}=\alpha_{2,0}+\alpha_{2,1} U_{i}+\alpha_{2,2}^{\prime} X_{i}+\alpha_{2,3} t+\varepsilon_{2 i}
$$

where $\varepsilon_{1 i}, \varepsilon_{2 i} \sim N\left(0,0,1,1, \rho_{12}\right)$ and $\operatorname{corr}\left(\varepsilon_{1 i}, \varepsilon_{2 i}\right)=\rho_{12}$ and $D_{1}$ and $D_{2}$ represent the following binary outcomes:

$$
D_{1}=\left\{\begin{array}{ll}
1 & \text { if } W_{i}>0 \\
0 & \text { if } W_{i} \leq 0
\end{array} \quad D_{2}=\left\{\begin{array}{ll}
1 & \text { if } M_{i}>0 \\
0 & \text { if } M_{i} \leq 0
\end{array}\right. \text {. }\right.
$$

Since we are interested in respondents who choose to work (i.e. $D_{1}=1$ ) and moonlight (i.e. $D_{2}=1$ ), the probability of this joint event $(P)$ can be described as follows:

(5) $\quad P=\operatorname{Pr}\left[W_{i}>0, M_{i}>0\right]=\operatorname{Pr}\left[D_{1}=1, D_{2}=1\right]=\mathrm{G}\left(C_{1}, C_{2}, \rho_{12}\right)$, where:

$$
C_{1}=\left(\alpha_{1,0}+\alpha_{1,1} U_{i}+\alpha_{1,2}^{\prime} X_{i}+\alpha_{1,3} t+\alpha_{1,4} Z_{i}+\varepsilon_{1 i}\right), C_{2}=\left(\alpha_{2,0}+\alpha_{2,1} U_{i}+\alpha_{2,2}^{\prime} X_{i}+\alpha_{2,3} t+\varepsilon_{2 i}\right), \mathrm{G}(.)
$$

is the bivariate normal density function, and $\rho_{12}$ is the correlation coefficient. Hence, the likelihood function for the bivariate probit with selection specified in equations (3)-(4) is given by:

$$
L=\prod_{\substack{D_{1}=1 \\ D_{2}=1}} G\left(C_{1}, C_{2}, \rho_{12}\right) \prod_{\substack{D_{1}=1 \\ D_{2}=0}} G\left(C_{1}, C_{2},-\rho_{12}\right) \prod_{D_{1}=0} F\left(-C_{1}\right)
$$

where the first term of the likelihood function corresponds to moonlighters, the second term to non-moonlighting workers, and the third term to non-workers. The bivariate probit is identified through the use of family background characteristics included in vector $Z_{i}$. These family background characteristics are highly correlated with the individual likelihood of being at work, 
whereas they are not important in explaining the individual likelihood to moonlight. Therefore, when statistically different from zero, they can help us identify the aforementioned system.

\section{B) Results}

Model (4) in Table 4 and Table 5 shows the results from estimating the bivariate probit with sample selection described by equation (6) for men and women, respectively. The unemployment rate coefficient estimate in model (4), Table 4 indicates that, once we take into account the selection into employment among men, male moonlighting rates over the 20-year period under examination (from 1979 through the year 2000) were procyclical. In particular, an increase of 1 percentage point in the unemployment rate significantly lowers the likelihood of holding multiple jobs by approximately 0.4 percent among men. This implies a reduction in the average male moonlighting rate from an average of 6.9 percent over the entire period (use Table 1 as reference) to 6.6 percent.

Likewise, the unemployment rate coefficient estimate in model (4), Table 5 suggests female moonlighting procyclicality, contrary to the counter-cyclical nature of moonlighting rates implied by the coefficient estimates in models (1) through (3). As a result, modeling the selection into employment in the case of women significantly alters the relationship between unemployment and moonlighting rates, with the latter now decreasing by 0.7 percent from 7.4 percent over the period under consideration (refer to Table 1) to 6.8 percent as the unemployment rate rises by 1 percentage point. As a result, for both employed men and women, the probability of moonlighting increases during economic expansions. The importance of accounting for the selection into employment when modeling female moonlighting rates is not surprising given the lower labor force participation rates among women. The reversal in the unemployment coefficient sign due to the correction for employment selection implies that 
economic expansions may serve as an opportunity for taking on a second job for workers with pre-existing labor force attachment. In what follows, we further examine the sensitivity of hours moonlighted to the business cycle while accounting, first, for the double selection into employment and, subsequently, into moonlighting.

\section{Moonlighting Hours over the Business Cycle}

\section{A) Methodology}

While the analysis in the previous sections informs on the impact of business cycles on the aggregate moonlighting rates of civilian men and women aged 14 to 21 (as of December 31, 1978), it fails to capture the average effect of business cycles on the moonlighter's hours on the second job. Thus, the question remains of whether moonlighting hours rise or fall with the business cycle for workers already holding multiple jobs. Note that we only observe the number of hours moonlighted for those individuals who first choose to work and, subsequently, decide to hold more than one job. In other words, the number of hours moonlighted is truncated for a large fraction of our sample. Under such circumstances, the distribution that applies to the sample data is a mixture of discrete and continuous distributions, rendering the use of OLS inappropriate. As such, following the analysis in the previous section, we model moonlighting hours through a three equation system that includes the selection rules described by equations (3) and (4), as well as equation (7) for moonlighting hours:

(3) Work Selection Rule: $W_{i}=\alpha_{1,0}+\alpha_{1,1} U_{i}+\alpha_{1,2}^{\prime} X_{i}+\alpha_{1,3} t+\alpha_{1,4} Z_{i}+\varepsilon_{1 i}$

(4) Multiple Job Holding Selection Rule: $M_{i}=\alpha_{2,0}+\alpha_{2,1} U_{i}+\alpha_{2,2}^{\prime} X_{i}+\alpha_{2,3} t+\varepsilon_{2 i}$

(7) Moonlighting Hours Equation: $h_{i}=\alpha_{3,0}+\alpha_{3,1} U_{i}+\alpha_{3,2}^{\prime} X_{i}+\alpha_{3,3} t+\varepsilon_{3 i}$ 
where the correlation matrix of the error term is given by $\Sigma=\left[\begin{array}{ccc}1 & \rho_{12} & \rho_{13} \\ \rho_{12} & 1 & \rho_{23} \\ \rho_{13} & \rho_{23} & 1\end{array}\right]$.

Following Tunali (1985), we can estimate the following equation of moonlighting hours by OLS:

$$
h_{i}=\alpha_{3,0}+\alpha_{3,1} U_{i}+\alpha_{3,2}^{\prime} X_{i}+\alpha_{3,3} t+\gamma_{W} \lambda_{W}+\gamma_{M} \lambda_{M}+\varpi_{3 i},
$$

where $\lambda_{w}$ and $\lambda_{M}$ are the equivalent of the inverse Mills ratios for the self-selection into work and into multiple job holding constructed using the consistent coefficient estimates and correlation coefficient ( $\rho_{12}$ ) obtained from the maximum likelihood estimation of equation (6). The expected value of the error term conditional on working and moonlighting is now zero (i.e. $\left.E\left(\varpi_{3 i} \mid D_{1}=1, D_{2}=1\right)=0\right)$, and the appropriate variance-covariance matrix is derived following Tunali (1985).

\section{B) Results}

The last columns in Table 4 and Table 5 display the coefficient estimates of the impact of a 1 percentage point increase in the unemployment rate on the hours moonlighted by men and women over the 20-year period under analysis. The estimates in model (4) showed that both men and women reduce their moonlighting rates when the unemployment rate goes up when we take into account the significant selection into employment that occurs among women. According to the figures in Table 4, model (5), a 1 percentage point increase in the unemployment rate reduces the weekly hours moonlighted by men by approximately 3.7 hours. Thus, for the typical male worker, a 1 percentage point increase in the unemployment rate would reduce weekly moonlighting hours from an average of 25 hours (see Appendix) to 21 hours. This suggests that moonlighting hours are procyclical, which is consistent with the findings of Bell et al (1997), who reject the notion that men moonlight as a hedge against unemployment. 
Stated differently, multiple job holders tend to moonlight more hours during periods of economic growth and potential labor shortages. However, female moonlighting hours are not significantly responsive to changes in the unemployment rate (Table 5, model (5)). This may be due to women's tendency to work fewer hours (e.g. as part-time workers) on the second job than men.

\section{Conclusions}

Our findings indicate that the incidence of moonlighting is strongly procyclical for men and for women when we take into account their selection into employment. However, conditioning on holding a second job, moonlighting hours are only procyclical in the case of men. In other words, moonlighting probabilities increase during economic expansions, suggesting that job availability may play a greater role in explaining moonlighting trends than job insecurity or economic distress. Procyclical moonlighting also reinforces the importance of job heterogeneity and primary job constraints as a motivating force for holding multiple jobs to the extent that economic expansions improve on the job opportunities and extra hours on the primary job available to workers. These findings are at odds with statements in the popular media and by advocacy groups about moonlighting being largely a byproduct of economic downturns. Instead, our findings support the study by Partridge (2002), who finds short-run moonlighting to be procyclical and states that "moonlighting appears to be a regional labor market shock absorber.” (pg. 438)

What is the implication of our findings for the literature on real wage cyclicality? To the extent that moonlighting is procyclical, observed average hourly real wages across all jobs will be procyclical in part due to the rising incidence of secondary job wages included in calculating average wages used in estimating real wage cyclicality. However, Conway and Kimmel (2001) compare primary and secondary job wages across age and education categories, primary and 
secondary job occupations, as well as family income status, and consistently find that on average, primary job wages exceed secondary job wages. Thus, it might be interesting to investigate the cyclicality of average real wages separately by sex and assess the potential role that differential moonlighting responses to economic downturns may have on real wage cyclicality.

Turning to the policy-relevance of our findings, our results point to the responsiveness of multiple job holding to growing employment opportunities as well as needs on the part of firms during economic expansions, thus serving as a "just-in-time” labor supply. To the extent that some researchers have argued that much of the job growth in the United States has been and is expected to occur disproportionately in the low wage sector, further analyses assessing the quality of secondary jobs and how they contribute to overall job quality could help clarify these predictions.

Finally, in regards to the tax treatment of second jobs, it is worth noting that workers satisfying short-term labor shortages by taking on a part-time second job bear the regressive character of the UI tax. Likewise, although employers can benefit from moonlighters taking second part-time jobs during economic expansions, the UI tax structure creates a disincentive for employers to create these jobs. Given the constructive role of moonlighting when it comes to responding to rising employment opportunities and needs on the part of firms during economic expansions, a policy change that avoids penalizing this type of employment could prove valuable. $^{16}$

\footnotetext{
${ }^{16}$ Robinson and Wadsworth (2005) consider another interesting policy issue, namely the potential impact of a minimum wage on multiple-job holding.
} 


\section{References}

Allen, W.D. 1998. “The Moonlighting Decision of Unmarried Men and Women: Family and Labor Market Influences,” Atlantic Economic Journal, Vol. 26, No. 2, pp. 190-205.

Anderson, Patricia M. and Bruce D. Meyer. 2003. "Unemployment Insurance Tax Burdens and Benefits: Funding Family Leave and Reforming the Payroll Tax,” NBER Working Paper No. 10043 (October), 30 pgs.

Averett, Susan L. 2001. “Moonlighting: Multiple Motives and Gender Differences,” Applied Economics Vol. 33, pp. 1391-1410.

Bell, David N.F., Robert A. Hart, and Robert E. Wright. 1997. "Double Job Holding in Great Britain," unpublished manuscript October (think they sent it to Journal of the Royal Statistical Society, Series A).

Bell, David N.F., Robert A. Hart, and Robert E. Wright. 1997. "Multiple-Job Holding as a 'Hedge” Against Unemployment,” CEPR research programme on UK Labour Market: Microeconomics Imperfections and Institutional Features; 19 pgs.

Boheim, Renee and Mark Taylor. 2004. “And in the Evening She’s a Singer with Band Second Jobs, Plight or Pleasure?” IZA Discussion Paper No. 1081, March.

Conway, Karen and Jean Kimmel. 1998. Male Labor Supply Estimates and the Decision to Moonlight, Labour Economics 5(2), pp. 135-166.

Devereux, Paul J. 2001. "The Cyclicality of Real Wages Within Employer-Employee Matches.” Industrial and Labor Relations Review, Vol. 54, No. 4, pp. 835-850.

Goodman, Wiliam C. 2001. "Employment in Service Industries Affected by Recessions and Expansions,” Monthly Labor Review, pp. 3-11.

Hart, Robert A. and James R. Malley. 1999. “On the Cyclicality and Stability of Real Earnings,” IZA Discussion Paper No. 45, 25 pgs.

Heineck, Guido and Johannes Schwarze. 2004. "Fly Me to the Moon: The Determinants of Secondary Jobholding in Germany and the UK," IZA Discussion Paper No. 1358 (October), 35 pgs.

Kimmel, Jean and Karen Conway. 2001. "Who Moonlights and Why? Evidence from the SIPP,” Industrial Relations 40(1), pp. 89-120.

Kimmel, Jean, and Lisa Powell. 1999. "Moonlighting Trends and Related Policy Issues in Canada and the United States,” Canadian Public Policy 25(2), pp. 207-231. 
Moulton, B. R. 1986. "Random Group Effects and the Precision of Regression Estimates," Journal of Econometrics, Vol. 32 (August), pp. 385-397.

Partridge, Mark. 2002. "Moonlighting in a High Growth Economy: Evidence from U.S. StateLevel Data," Growth and Change Vol. 33, No. 4 (Fall), pp. 424-452.

Robinson, Helen and Jonathan Wadsworth. 2004. "Did the Minimum Wage Affect the Incidence of Second Job Holding in Britain?” EALE conference 2004, unpublished manuscript.

Shin, Donggyun. 1994. “Cyclicality of Real Wages among Young Men.” Economic Letters, Vol 46, No. 2, pp. 137-42.

Shin, Donggyun and Gary Solon. 2004. "New Evidence on Real Wage Cyclicality Within Employer-Employee Matches," unpublished manuscript, February, 23 pgs.

Solon, Gary, Robert Barsky, and Jonathan A. Parker. 1994. "Measuring the Cyclicality of Real Wages: How Important is Composition Bias?” The Quarterly Journal of Economics CIX(1), February, pp. 1-25.

Solon, Gary, Warren Whatley, and Ann Huff Stevens. 1997. "Wage Changes and Intrafirm Job Mobility over the Business Cycle: Two Case Studies." Industrial and Labor Relations Review, Vol. 50, No. 3 (April), pp. 402-15.

StataCorp. 2003. Stata Cross-Sectional Time-Series. Reference Manual. Release 8.0. College Station, TX: Stata Corporation.

Stinson, John F. (Jr.). 1990. "Multiple jobholding up sharply in the eighties," Monthly Labor Review 113(7), July, pp. 3-10.

Stinson, John F. (Jr.) 1987. "Moonlighting: a key to differences in measuring employment growth,” Monthly Labor Review 110(2), February, pp. 30-31. 
Table 1

Working and Moonlighting Rates by Gender

\begin{tabular}{lcccccc}
\hline \multirow{2}{*}{ Variables } & \multicolumn{2}{c}{$\mathbf{1 9 8 0}$} & \multicolumn{2}{c}{$\mathbf{1 9 9 0}$} & \multicolumn{2}{c}{$\mathbf{2 0 0 0}$} \\
Working & Moonlighting & Working & Moonlighting & Working & Moonlighting \\
\hline \multirow{2}{*}{ Men } & 0.45 & 0.05 & 0.58 & 0.08 & 0.50 & 0.07 \\
Women & 0.49 & 0.05 & 0.67 & 0.09 & 0.53 & 0.07 \\
\hline
\end{tabular}

Notes: Authors' tabulations using the NLSY79.

Table 2A

Single versus Dual Job holders: Males

(Only Includes Workers)

\begin{tabular}{lcccccc}
\hline Variables & \multicolumn{2}{c}{1980} & \multicolumn{2}{c}{$\mathbf{1 9 9 0}$} & \multicolumn{2}{c}{$\mathbf{2 0 0 0}$} \\
One Job & $\begin{array}{c}\text { Two Plus } \\
\text { Jobs }\end{array}$ & One Job & $\begin{array}{c}\text { Two Plus } \\
\text { Jobs }\end{array}$ & $\begin{array}{c}\text { One Job } \\
\text { Two Plus } \\
\text { Jobs }\end{array}$ \\
\hline Percent White & 0.76 & 0.79 & 0.70 & 0.70 & 0.64 & 0.64 \\
Percent Black & 0.19 & 0.16 & 0.24 & 0.25 & 0.30 & 0.30 \\
Highest Grade Completed & 11.77 & 12.89 & 13.16 & 13.68 & 13.33 & 13.77 \\
Married & 0.18 & 0.14 & 0.56 & 0.45 & 0.58 & 0.55 \\
\# Kids & 0.19 & 0.10 & 1.14 & 0.95 & 1.55 & 1.64 \\
Urban & 0.79 & 0.82 & 0.80 & 0.82 & 0.76 & 0.76 \\
\hline
\end{tabular}

Notes: Authors' tabulations using the NLSY79.

Table 2B

Single versus Dual Job holders: Females

(Only Includes Workers)

\begin{tabular}{lcccccc}
\hline & \multicolumn{2}{c}{$\mathbf{1 9 8 0}$} & \multicolumn{1}{c}{$\mathbf{1 9 9 0}$} & \multicolumn{2}{c}{$\mathbf{2 0 0 0}$} \\
Variables & One Job & $\begin{array}{c}\text { Two Plus } \\
\text { Jobs }\end{array}$ & One Job & $\begin{array}{c}\text { Two Plus } \\
\text { Jobs }\end{array}$ & $\begin{array}{c}\text { One Job } \\
\text { Two Plus } \\
\text { Jobs }\end{array}$ \\
\hline Percent White & 0.73 & 0.81 & 0.71 & 0.71 & 0.67 & 0.64 \\
Percent Black & 0.22 & 0.14 & 0.23 & 0.24 & 0.27 & 0.32 \\
Highest Grade Completed & 11.28 & 12.10 & 12.75 & 13.16 & 13.12 & 13.31 \\
Married & 0.13 & 0.12 & 0.53 & 0.50 & 0.63 & 0.58 \\
\# Kids & 0.10 & 0.09 & 0.80 & 0.86 & 1.29 & 0.74 \\
Urban & 0.79 & 0.83 & 0.80 & 0.80 & 0.77 \\
\hline
\end{tabular}

Notes: Authors' tabulations using the NLSY79. 
Table 3A

Job Status Transitions: Men

\begin{tabular}{lcccc}
\hline Period (t-1) & No Job & $\begin{array}{c}\text { Period t } \\
\text { One Job }\end{array}$ & Two Plus Jobs & Total \\
\hline \multirow{2}{*}{ No Job } & 79.44 & 19.46 & 1.09 & 100 \\
& 80.25 & 20.31 & 7.43 & 47.72 \\
One Job & 18.74 & 74.10 & 7.16 & 400 \\
\multirow{2}{*}{ Two Plus Jobs } & 18.04 & 73.67 & 46.33 & 100 \\
& 11.91 & 40.39 & 47.71 & 6.81 \\
\hline \multirow{2}{*}{ Total } & 1.72 & 6.01 & 46.24 & 100 \\
& 47.25 & 45.73 & 100 & 100 \\
\hline
\end{tabular}

Notes: Authors' tabulations using the NLSY79.

Table 3B

Job Status Transitions: Women

\begin{tabular}{|c|c|c|c|c|}
\hline Period (t-1) & No Job & $\begin{array}{l}\text { Period t } \\
\text { One Job }\end{array}$ & Two Plus Jobs & Total \\
\hline \multirow[t]{2}{*}{ No Job } & 78.04 & 20.61 & 1.35 & 100 \\
\hline & 78.67 & 16.85 & 7.52 & 41.75 \\
\hline \multirow[t]{2}{*}{ One Job } & 15.62 & 77.55 & 6.83 & 100 \\
\hline & 19.22 & 77.38 & 46.29 & 50.96 \\
\hline \multirow[t]{2}{*}{ Two Plus Jobs } & 11.96 & 40.45 & 47.58 & 100 \\
\hline & 2.11 & 5.78 & 46.18 & 7.29 \\
\hline \multirow{2}{*}{ Total } & 41.41 & 51.07 & 7.51 & 100 \\
\hline & 100 & 100 & 100 & 100 \\
\hline
\end{tabular}

Notes: Authors' tabulations using the NLSY79. 
Table 4: Moonlighting Results for Men

\begin{tabular}{|c|c|c|c|c|c|c|}
\hline Variables & $\begin{array}{c}\text { Model (1) } \\
\text { Pooled } \\
\text { Probit } \\
\text { Coefficient } \\
\text { (s.e.) } \\
\text { [m.e.] } \\
\end{array}$ & $\begin{array}{c}\text { Model (2) } \\
\text { Random Effects } \\
\text { Probit } \\
\text { Coefficient } \\
\text { (s.e.) } \\
\text { [m.e.] } \\
\end{array}$ & $\begin{array}{c}\text { Model (3) } \\
\text { Fixed Effects } \\
\text { Logit } \\
\text { Coefficient } \\
\text { (s.e.) } \\
\text { [m.e.] } \\
\end{array}$ & $\begin{array}{c}\text { Probit with } \\
\text { Work Eq. } \\
\text { Coefficient } \\
\text { (s.e.) } \\
\text { [m.e.] } \\
\end{array}$ & $\begin{array}{l}\text { del (4) } \\
\text { ection for Working } \\
\text { Moonlighting Eq. } \\
\text { Coefficient } \\
\text { (s.e.) } \\
\text { [m.e.] } \\
\end{array}$ & $\begin{array}{c}\text { Model (5) } \\
\text { OLS for } \\
\text { Moonlight Hours } \\
\text { Coefficient } \\
\text { (s.e.) } \\
\text { [m.e.] } \\
\end{array}$ \\
\hline $\begin{array}{l}\text { Unemployment } \\
\text { Rate }\end{array}$ & $\begin{array}{c}-.0036 \\
(.0064) \\
{[-.0005]}\end{array}$ & $\begin{array}{c}-.0062 \\
(.0069) \\
{[-.0005]}\end{array}$ & $\begin{array}{c}-.0063 \\
(.0134) \\
{[-.0011]}\end{array}$ & $\begin{array}{c}.0473 * * * \\
(.0033) \\
{[.0116]}\end{array}$ & $\begin{array}{c}-.0173 * * * \\
(.0080) \\
{[-.0039]}\end{array}$ & $\begin{array}{c}-3.6721 * * * \\
(.8513)\end{array}$ \\
\hline Black & $\begin{array}{c}-.0974 * * * \\
(.0302) \\
{[-.0135]}\end{array}$ & $\begin{array}{c}-.1603 * * * \\
(.0336) \\
{[-.0127]}\end{array}$ & - & $\begin{array}{c}-.1665 * * * \\
(.0259) \\
{[-.0428]}\end{array}$ & $\begin{array}{c}-.0513 * \\
(.0368) \\
{[-.0113]}\end{array}$ & $\begin{array}{l}-3.1644^{*} \\
(2.2094)\end{array}$ \\
\hline Other Race & $\begin{array}{c}-.0741^{*} \\
(.0302) \\
{[-.0102]}\end{array}$ & $\begin{array}{c}-.1522 * * * \\
(.0623) \\
{[-.0115]}\end{array}$ & - & $\begin{array}{l}.0253^{*} \\
(.0499) \\
{[.0061]}\end{array}$ & $\begin{array}{c}-.0891 * \\
(.0593) \\
{[-.0191]}\end{array}$ & $\begin{array}{c}-8.9383 * * \\
(4.2423)\end{array}$ \\
\hline Age & $\begin{array}{c}.0033 \\
(.0048) \\
{[.0005]}\end{array}$ & $\begin{array}{c}-.0007 \\
(.0049) \\
{[-.00006]}\end{array}$ & $\begin{array}{c}-.0454 * * * \\
(.0185) \\
{[-.0077]}\end{array}$ & $\begin{array}{c}.0247 * * * \\
(.0040) \\
{[.0060]}\end{array}$ & $\begin{array}{c}-.0090 * \\
(.0054) \\
{[-.0020]}\end{array}$ & $\begin{array}{l}-1.1344 * * * \\
(.4325)\end{array}$ \\
\hline Highest Grade & $\begin{array}{c}.0891 * * * \\
(.0051) \\
{[.0129]}\end{array}$ & $\begin{array}{c}.1038 * * * \\
(.0054) \\
{[.0088]}\end{array}$ & $\begin{array}{c}.1174 * * * \\
(.0165) \\
{[.0199]}\end{array}$ & $\begin{array}{c}.1591^{* * *} \\
(.0056) \\
{[.0390]}\end{array}$ & $\begin{array}{c}.0379 * * * \\
(.0139) \\
{[.0084]}\end{array}$ & $\begin{array}{c}3.6354 * * * \\
(1.4324)\end{array}$ \\
\hline Married & $\begin{array}{c}.1579 * * * \\
(.0232) \\
{[.0226]}\end{array}$ & $\begin{array}{c}-.2234 * * * \\
(.0208) \\
{[-.0187]}\end{array}$ & $\begin{array}{c}-.4496 * * * \\
(.0441) \\
{[-.0772]}\end{array}$ & $\begin{array}{c}.1104 * * * \\
(.0170) \\
{[.0270]}\end{array}$ & $\begin{array}{c}-.2582 * * * \\
(.0240) \\
{[-.0575]}\end{array}$ & $\begin{array}{c}-32.8790 * * * \\
(11.1560)\end{array}$ \\
\hline Young Children & $\begin{array}{c}-.2683 * * * \\
(.0241) \\
{[-.0368]}\end{array}$ & $\begin{array}{c}-.3133 * * * \\
(.0225) \\
{[-.0248]}\end{array}$ & $\begin{array}{c}-.5582 * * * \\
(.0453) \\
{[-.0994]}\end{array}$ & $\begin{array}{c}-.4065 * * * \\
(.0158) \\
{[-.1056]}\end{array}$ & $\begin{array}{c}-.0527^{*} \\
(.0461) \\
{[-.0117]}\end{array}$ & $\begin{array}{c}-9.7421 * * * \\
(2.0676)\end{array}$ \\
\hline No. of Children & $\begin{array}{l}-.0187 * \\
(.0127) \\
{[-.0027]}\end{array}$ & $\begin{array}{c}-.0251^{* *} \\
(.0115) \\
{[-.0021]}\end{array}$ & $\begin{array}{l}-.0399 * \\
(.0269) \\
{[-.0067]}\end{array}$ & $\begin{array}{c}-.2100 * * * \\
(.0107) \\
{[-.0516]}\end{array}$ & $\begin{array}{c}.0741^{* * *} \\
(.0202) \\
{[.0166]}\end{array}$ & $\begin{array}{c}9.7430 * * * \\
(3.4815)\end{array}$ \\
\hline Health Limitations & $\begin{array}{c}-.0723 * * \\
(.0349) \\
{[-.0099]}\end{array}$ & $\begin{array}{c}-.0839 * * \\
(.0368) \\
{[-.0067]}\end{array}$ & $\begin{array}{c}-.1238 * * * \\
(.0751) \\
{[-.0216]}\end{array}$ & $\begin{array}{c}-.4213 * * * \\
(.0259) \\
{[-.1219]}\end{array}$ & $\begin{array}{c}.1221 * * * \\
(.0510) \\
{[.0289]}\end{array}$ & $\begin{array}{c}16.3330 * * * \\
(6.0336)\end{array}$ \\
\hline $\begin{array}{l}\text { Previous Year } \\
\text { Non-labor Income }\end{array}$ & $\begin{array}{c}-4.54 \mathrm{e}^{* *} \\
(2.13 \mathrm{e}) \\
{[-6.56 \mathrm{e}]}\end{array}$ & $\begin{array}{c}-2.98 \mathrm{e}^{*} \\
(2.08 \mathrm{e}) \\
{[-2.54 \mathrm{e}]}\end{array}$ & $\begin{array}{c}-3.67 \mathrm{e}^{*} \\
(3.98 \mathrm{e}) \\
{[-6.22 \mathrm{e}]}\end{array}$ & $\begin{array}{c}-2.21 \mathrm{e}^{*} \\
(1.81 \mathrm{e}) \\
{[-5.44 \mathrm{e}]}\end{array}$ & $\begin{array}{l}5.83 e^{*} \\
(2.47 \mathrm{e}) \\
{[1.31 \mathrm{e}]}\end{array}$ & $\begin{array}{l}.00005^{* *} \\
(.00002)\end{array}$ \\
\hline Urban & $\begin{array}{l}.0442 * \\
(.0300) \\
{[.0063]}\end{array}$ & $\begin{array}{l}.0617 * * \\
(.0272) \\
{[.0052]}\end{array}$ & $\begin{array}{c}.1261^{* * *} \\
(.0585) \\
{[.0213]}\end{array}$ & $\begin{array}{c}.1515^{* * *} \\
(.0234) \\
{[.0372]}\end{array}$ & $\begin{array}{l}.0150 * \\
(.0342) \\
{[.0034]}\end{array}$ & $\begin{array}{l}1.8174 * * \\
(1.0805)\end{array}$ \\
\hline SMSA & $\begin{array}{c}-.0406 * * * \\
(.0115) \\
{[-.0058]}\end{array}$ & $\begin{array}{c}-.0423 * * * \\
(.0114) \\
{[-.0036]}\end{array}$ & $\begin{array}{c}-.03968 * \\
(.0254) \\
{[-.0067]}\end{array}$ & $\begin{array}{c}-.0535 * * * \\
(.0094) \\
{[-.0131]}\end{array}$ & $\begin{array}{c}-.0179 \\
(.0140) \\
{[-.0040]}\end{array}$ & $\begin{array}{c}-1.6867 * * \\
(.8024)\end{array}$ \\
\hline Northeast & $\begin{array}{c}-.2496 \\
(.2479) \\
{[-.0319]}\end{array}$ & $\begin{array}{c}-.3301 \\
(.3374) \\
{[-.0232]}\end{array}$ & $\begin{array}{c}-.7249 \\
(.6814) \\
{[-.1393]}\end{array}$ & $\begin{array}{c}.6947 * * * \\
(.1945) \\
{[.1329]}\end{array}$ & $\begin{array}{c}.4895 * \\
(.3065) \\
{[-.0911]}\end{array}$ & $\begin{array}{c}-71.4464 * * * \\
(25.2050)\end{array}$ \\
\hline South & $\begin{array}{c}.0050 \\
(.1635) \\
{[.0007]}\end{array}$ & $\begin{array}{c}-.0475 \\
(.2739) \\
{[-.0040]}\end{array}$ & $\begin{array}{c}-.1956 \\
(.6012) \\
{[-.0335]}\end{array}$ & $\begin{array}{c}.1531 \\
(.1343) \\
{[.0369]}\end{array}$ & $\begin{array}{c}.0134 \\
(.2198) \\
{[.0030]}\end{array}$ & $\begin{array}{c}-4.4039 * * \\
(2.0935)\end{array}$ \\
\hline West & $\begin{array}{c}-.0762 \\
(.2764) \\
{[-.0106]}\end{array}$ & $\begin{array}{c}.0254 \\
(.3374) \\
{[.0022]}\end{array}$ & $\begin{array}{l}.3047 * \\
(.6775) \\
{[.0488]}\end{array}$ & $\begin{array}{c}-.0557 * \\
(.1860) \\
{[-.0139]}\end{array}$ & $\begin{array}{c}-.1814 \\
(.3015) \\
{[-.0382]}\end{array}$ & $\begin{array}{c}-45.6271^{* * *} \\
(8.0006)\end{array}$ \\
\hline Time Trend & $\begin{array}{c}.0161 * * * \\
(.0056) \\
{[.0023]}\end{array}$ & $\begin{array}{c}.0239 * * * \\
(.0058) \\
{[.0020]}\end{array}$ & $\begin{array}{c}.1054 * * * \\
(.0219) \\
{[.0178]}\end{array}$ & $\begin{array}{c}.0209 * * * \\
(.0046) \\
{[.0051]}\end{array}$ & $\begin{array}{l}.0027 * \\
(.0062) \\
{[.0006]}\end{array}$ & $\begin{array}{c}.1585 \\
(.1868)\end{array}$ \\
\hline
\end{tabular}


Table 4 - Continued

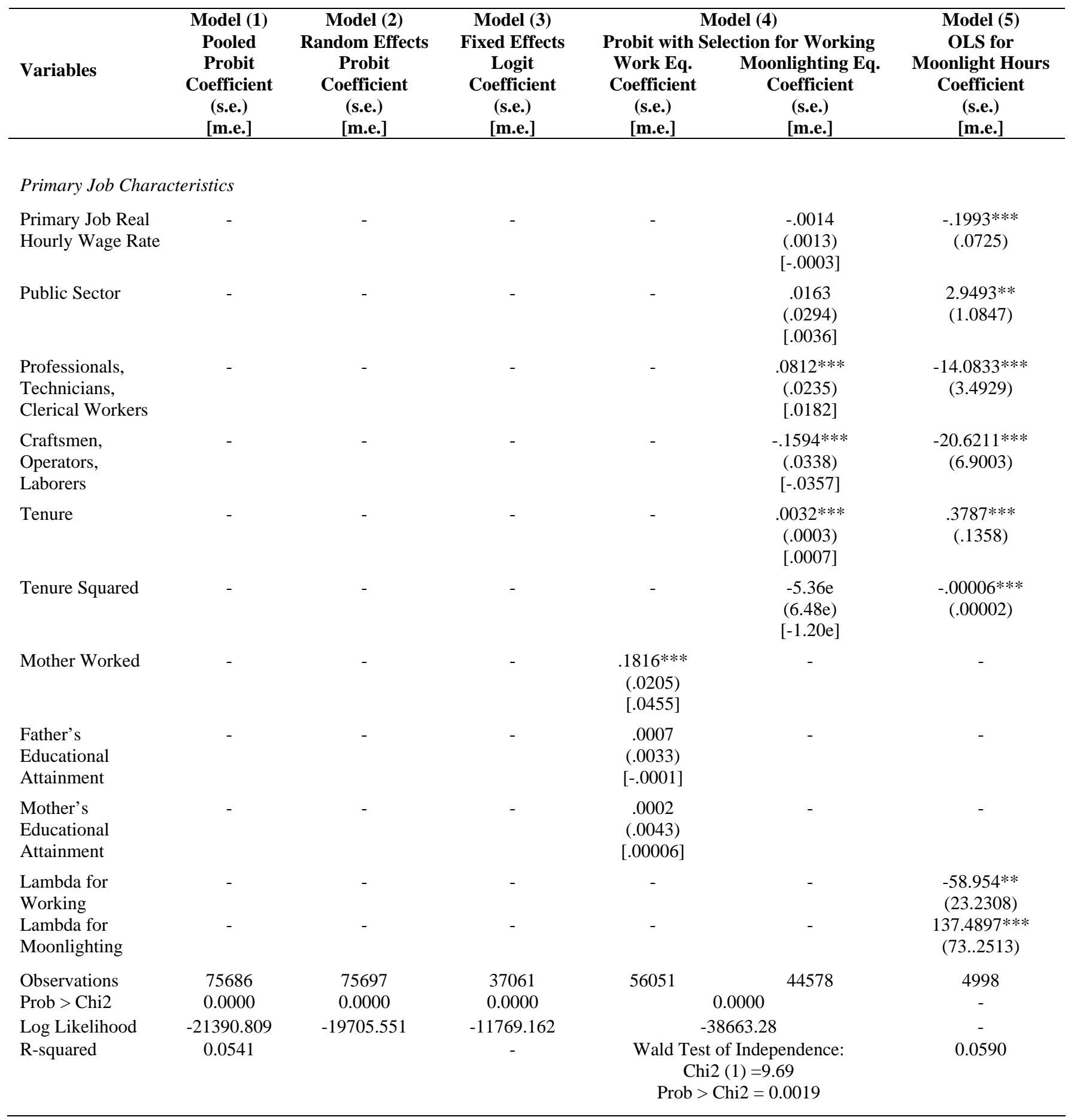

Notes: All regressions include state dummies and a constant. *** Signifies statistically different from zero at the $1 \%$ level or better, $* *$ at the $5 \%$ level or better and *at the $10 \%$ level or better. 
Table 5: Moonlighting Results for Women

\begin{tabular}{|c|c|c|c|c|c|c|}
\hline Variables & $\begin{array}{c}\text { Model (1) } \\
\text { Pooled } \\
\text { Probit } \\
\text { Coefficient } \\
\text { (s.e.) } \\
\text { [m.e.] } \\
\end{array}$ & $\begin{array}{c}\text { Model (2) } \\
\text { Random Effects } \\
\text { Probit } \\
\text { Coefficient } \\
\text { (s.e.) } \\
\text { [m.e.] } \\
\end{array}$ & $\begin{array}{c}\text { Model (3) } \\
\text { Fixed Effects } \\
\text { Logit } \\
\text { Coefficient } \\
\text { (s.e.) } \\
\text { [m.e.] } \\
\end{array}$ & $\begin{array}{c} \\
\text { Probit with } \\
\text { Work Eq. } \\
\text { Coefficient } \\
\text { (s.e.) } \\
\text { [m.e.] }\end{array}$ & $\begin{array}{l}\text { Model (4) } \\
\text { Selection for Working } \\
\text { Moonlighting Eq. } \\
\text { Coefficient } \\
\text { (s.e.) } \\
\text { [m.e.] } \\
\end{array}$ & $\begin{array}{c}\text { Model (5) } \\
\text { OLS for } \\
\text { Moonlight Hours } \\
\text { Coefficient } \\
\text { (s.e.) } \\
\text { [m.e.] } \\
\end{array}$ \\
\hline $\begin{array}{l}\text { Unemployment } \\
\text { Rate }\end{array}$ & $\begin{array}{c}.0115^{* * *} \\
(.0059) \\
{[.0019]}\end{array}$ & $\begin{array}{c}.0114^{* * *} \\
(.0068) \\
{[.0012]}\end{array}$ & $\begin{array}{l}.0231 * \\
(.0131) \\
{[.0044]}\end{array}$ & $\begin{array}{c}.0786 * * * \\
(.0045) \\
{[.0084]}\end{array}$ & $\begin{array}{c}-.0273 * * * \\
(.0065) \\
{[-.0067]}\end{array}$ & $\begin{array}{l}-.3385 \\
(.8843)\end{array}$ \\
\hline Black & $\begin{array}{c}-.0330 * \\
(.0293) \\
{[-.0056]}\end{array}$ & $\begin{array}{c}-.0749 * \\
(.0333) \\
{[-.0078]}\end{array}$ & & $\begin{array}{c}-.4392 * * * \\
(.0236) \\
{[-.0579]}\end{array}$ & $\begin{array}{c}.1527 * * * \\
(.0337) \\
{[.0389]}\end{array}$ & $\begin{array}{c}.0227 \\
(4.6479)\end{array}$ \\
\hline Other Race & $\begin{array}{c}-.0909 * * \\
(.0493) \\
{[-.0148]}\end{array}$ & $\begin{array}{c}-.1103 * * \\
(.0600) \\
{[-.0109]}\end{array}$ & & $\begin{array}{c}-.2774 * * * \\
(.0435) \\
{[-.0361]}\end{array}$ & $\begin{array}{c}.0353 \\
(.0528) \\
{[.0087]}\end{array}$ & $\begin{array}{c}-2.111 \\
(2.0906)\end{array}$ \\
\hline Age & $\begin{array}{c}-.0068 * \\
(.0047) \\
{[-.0012]}\end{array}$ & $\begin{array}{c}-.0122 * * \\
(.0049) \\
{[.0013]}\end{array}$ & $\begin{array}{c}-.0762 * * * \\
(.0183) \\
{[-.0144]}\end{array}$ & $\begin{array}{c}.0555 * * * \\
(.0038) \\
{[.0059]}\end{array}$ & $\begin{array}{c}-.0313 * * * \\
(.0050) \\
{[-.0077]}\end{array}$ & $\begin{array}{c}.5575 \\
(.8834)\end{array}$ \\
\hline Highest Grade & $\begin{array}{c}.0571 * * * \\
(0047) \\
{[.0098]}\end{array}$ & $\begin{array}{c}.0641^{* * * *} \\
(.0050) \\
{[.0069]}\end{array}$ & $\begin{array}{c}.0824 * * * \\
(.0166) \\
{[.0156]}\end{array}$ & $\begin{array}{c}.1051^{* * *} \\
(.0055) \\
{[.0112]}\end{array}$ & $\begin{array}{l}.0011 * \\
(.0071) \\
{[.0003]}\end{array}$ & $\begin{array}{c}-.8178 * * * \\
(.2859)\end{array}$ \\
\hline Married & $\begin{array}{c}-.0035 \\
(.0261) \\
{[-.0006]}\end{array}$ & $\begin{array}{c}-.0658 * * * \\
(.0231) \\
{[-.0070]}\end{array}$ & $\begin{array}{c}-.1813 * * * \\
(.0475) \\
{[-.0345]}\end{array}$ & $\begin{array}{c}.4426 * * * \\
(.0221) \\
{[.0453]}\end{array}$ & $\begin{array}{c}-.1634 * * * \\
(.0282) \\
{[-.0394]}\end{array}$ & $\begin{array}{c}-.9176 \\
(5.0154)\end{array}$ \\
\hline Young Children & $\begin{array}{c}-.0436 * \\
(.0273) \\
{[-.0074]}\end{array}$ & $\begin{array}{c}-.0419 * \\
(.0251) \\
{[-.0044]}\end{array}$ & $\begin{array}{c}-.0691 * \\
(.0487) \\
{[-.0132]}\end{array}$ & $\begin{array}{c}.3039 * * * \\
(.0278) \\
{[.0287]}\end{array}$ & $\begin{array}{c}-.1176 * * * \\
(.0288) \\
{[-.0279]}\end{array}$ & $\begin{array}{c}2.4245 \\
(3.6207)\end{array}$ \\
\hline No. of Children & $\begin{array}{l}.0207^{*} \\
(.0138) \\
{[0036]}\end{array}$ & $\begin{array}{l}.0257 * * \\
(.0120) \\
{[.0027]}\end{array}$ & $\begin{array}{l}.0336 * \\
(.0249) \\
{[.0063]}\end{array}$ & $\begin{array}{c}-.0522 * * * \\
(.0130) \\
{[-.0055]}\end{array}$ & $\begin{array}{c}.0349 * * * \\
(.0142) \\
{[.0085]}\end{array}$ & $\begin{array}{c}-.8875 \\
(1.0808)\end{array}$ \\
\hline Health Limitations & $\begin{array}{c}-.0987 * * * \\
(.0425) \\
{[-.0159]}\end{array}$ & $\begin{array}{c}-.0917 * * \\
(.0444) \\
{[-.0092]}\end{array}$ & $\begin{array}{c}-.1000 * * * \\
(.0903) \\
{[-.0193]}\end{array}$ & $\begin{array}{c}.-7387 * * * \\
(.0307) \\
{[-.1314]}\end{array}$ & $\begin{array}{c}.3423 * * * \\
(.0491) \\
{[.0965]}\end{array}$ & $\begin{array}{c}-1.7340 \\
(10.0180)\end{array}$ \\
\hline $\begin{array}{l}\text { Previous Year } \\
\text { Non-labor Income }\end{array}$ & $\begin{array}{c}-2.22 \mathrm{e}^{*} \\
(1.97 \mathrm{e}) \\
{[-3.81 \mathrm{e}]}\end{array}$ & $\begin{array}{c}-3.20 \mathrm{e}^{*} \\
(2.07 \mathrm{e}) \\
{[-3.45 \mathrm{e}]}\end{array}$ & $\begin{array}{c}-6.64 \mathrm{e}^{*} \\
(3.90 \mathrm{e}) \\
{[-1.25 \mathrm{e}]}\end{array}$ & $\begin{array}{c}-1.46 \mathrm{e}^{*} \\
(1.51 \mathrm{e}) \\
{[-1.55 \mathrm{e}]}\end{array}$ & $\begin{array}{c}5.66 \mathrm{e}^{* * *} \\
(1.76 \mathrm{e}) \\
{[1.38 \mathrm{e}]}\end{array}$ & $\begin{array}{l}-4.50 \mathrm{e}^{*} \\
(.00001)\end{array}$ \\
\hline Urban & $\begin{array}{c}.0724^{* * *} \\
(.0307) \\
{[.0124]}\end{array}$ & $\begin{array}{c}.0746^{* * *} \\
(.0271) \\
{[.0080]}\end{array}$ & $\begin{array}{c}.0894^{*} \\
(.0589) \\
{[.0169]}\end{array}$ & $\begin{array}{c}.1564 * * * \\
(.0231) \\
{[.0167]}\end{array}$ & $\begin{array}{c}.0065 \\
(.0306) \\
{[.0016]}\end{array}$ & $\begin{array}{c}-2.7087 * * \\
(1.0660)\end{array}$ \\
\hline SMSA & $\begin{array}{c}-.0386 * * * \\
(.0122) \\
{[-.0066]}\end{array}$ & $\begin{array}{c}-.0371 * * * \\
(.0110) \\
{[-.0040]}\end{array}$ & $\begin{array}{c}-.0425 * * \\
(.0245) \\
{[-.0080]}\end{array}$ & $\begin{array}{c}-.0637 * * * \\
(.0092) \\
{[-.0067]}\end{array}$ & $\begin{array}{c}-.0044 \\
.0125 \\
{[-.0011]}\end{array}$ & $\begin{array}{l}.5035^{*} \\
(.4183)\end{array}$ \\
\hline Northeast & $\begin{array}{c}-.1227 \\
(.2245) \\
{[-.0199]}\end{array}$ & $\begin{array}{c}-.2768 \\
(.3090) \\
{[-.0256]}\end{array}$ & $\begin{array}{c}-.9566^{*} \\
(.6490) \\
{[-.2051]}\end{array}$ & $\begin{array}{c}.0206 \\
(.1765) \\
{[.0022]}\end{array}$ & $\begin{array}{c}-.2666^{*} \\
(.2323) \\
{[-.0595]}\end{array}$ & $\begin{array}{c}-57.7033^{* * *} \\
(16.1477)\end{array}$ \\
\hline South & $\begin{array}{c}.2478 * \\
(.1683) \\
{[.0443]}\end{array}$ & $\begin{array}{c}.2484 \\
(.2541) \\
{[.0282]}\end{array}$ & $\begin{array}{c}.4743 \\
(.5571) \\
{[.0862]}\end{array}$ & $\begin{array}{c}.2481^{* * *} \\
(.1039) \\
{[.0251]}\end{array}$ & $\begin{array}{l}.2882 * * \\
(.1540) \\
{[.0732]}\end{array}$ & $\begin{array}{c}-77.4948 * * * \\
(19.5675)\end{array}$ \\
\hline West & $\begin{array}{c}.3963 * * * \\
(.1533) \\
{[.0789]}\end{array}$ & $\begin{array}{c}.4094 \\
(.4336) \\
{[.0537]}\end{array}$ & $\begin{array}{l}.5267^{*} \\
(.8660) \\
{[.0919]}\end{array}$ & $\begin{array}{c}.8232 * * * \\
(.2958) \\
{[.0610]}\end{array}$ & $\begin{array}{c}.1705 \\
(.2497) \\
{[.0437]}\end{array}$ & $\begin{array}{c}-91.9727^{* * * *} \\
(26.7020)\end{array}$ \\
\hline Time Trend & $\begin{array}{c}.0249 * * * \\
(.0055) \\
{[.0043]}\end{array}$ & $\begin{array}{c}.0335 * * * \\
(.0058) \\
{[.0036]}\end{array}$ & $\begin{array}{c}.1307 * * * \\
(.0213) \\
{[.0247]}\end{array}$ & $\begin{array}{c}-.0052 * \\
(.0043) \\
{[-.0005]}\end{array}$ & $\begin{array}{c}.0152^{* * *} \\
(.0054) \\
{[.0037]}\end{array}$ & $\begin{array}{l}-.4065 \\
(.4221)\end{array}$ \\
\hline
\end{tabular}


Table 5 - Continued

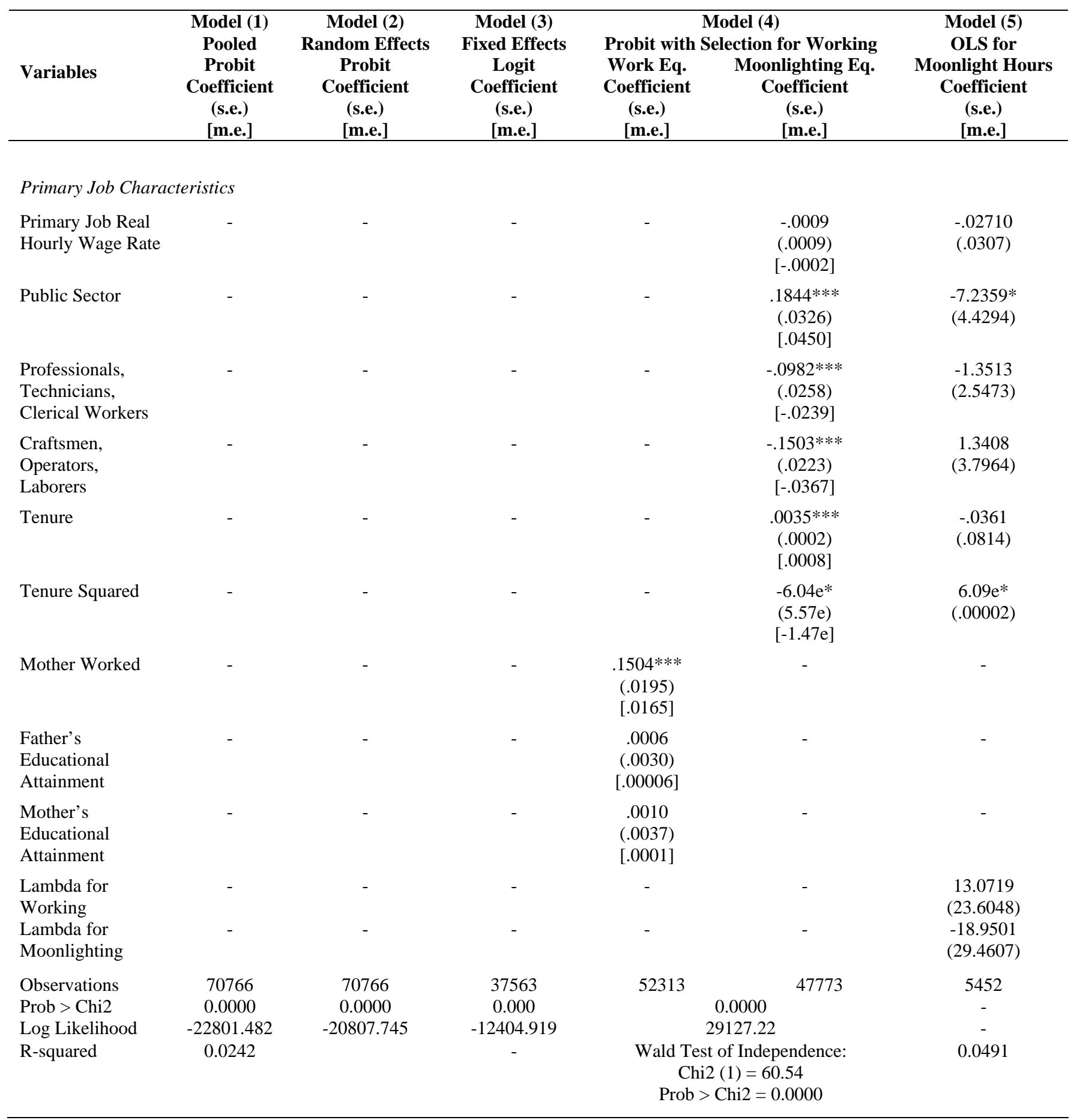

Notes: All regressions include state dummies and a constant. *** Signifies statistically different from zero at the $1 \%$ level or better, $* *$ at the $5 \%$ level or better and *at the $10 \%$ level or better. 
Figures 1 through 3

Moonlighting Rates over the Business Cycle
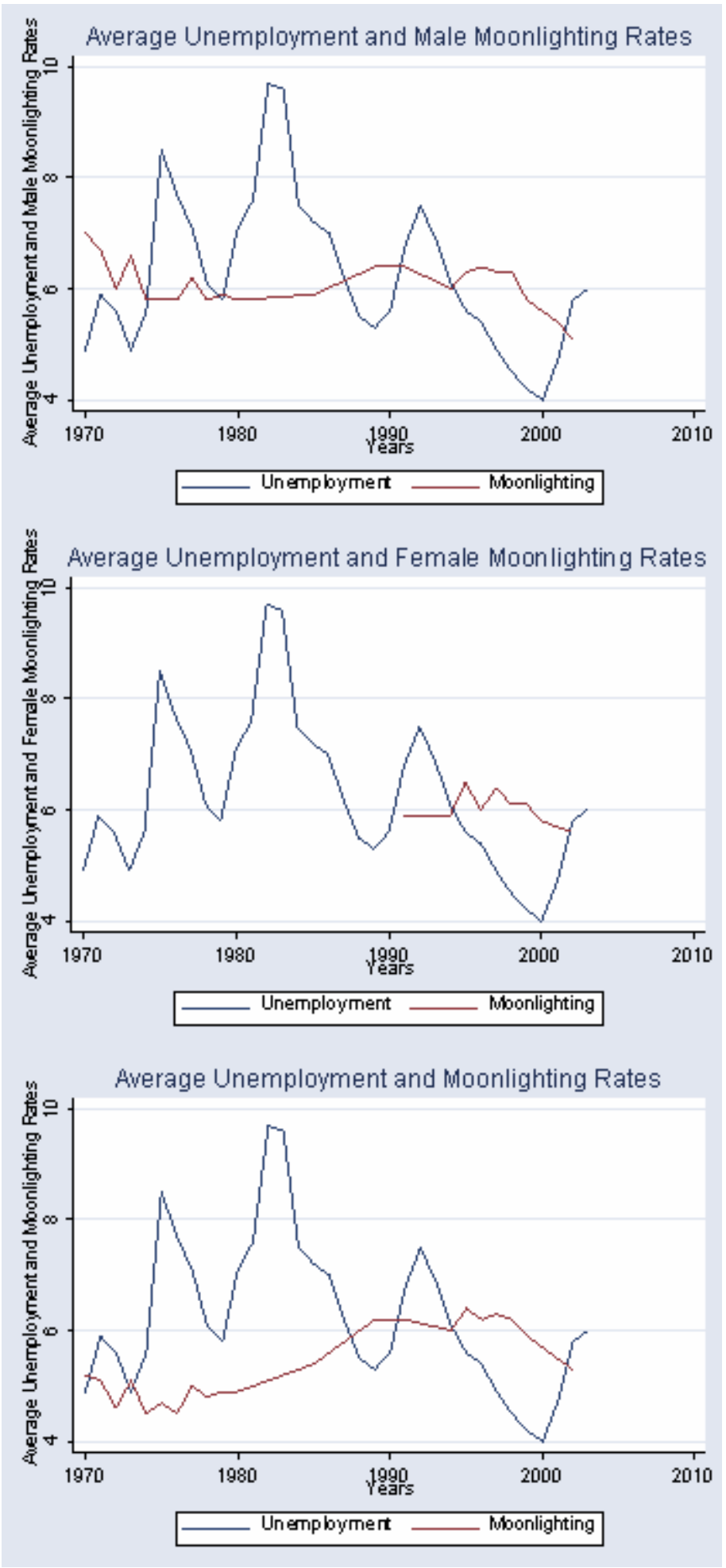
Appendix Table

Means and Standard Deviations in Parentheses

\begin{tabular}{|c|c|c|c|c|c|c|}
\hline \multirow{2}{*}{ Variables } & \multicolumn{3}{|c|}{ Women } & \multicolumn{3}{|c|}{ Men } \\
\hline & No Job & One Job & Moonlighter & No Job & One Job & Moonlighter \\
\hline White & $\begin{array}{c}0.64 \\
(0.47)\end{array}$ & $\begin{array}{c}0.70 \\
(0.46)\end{array}$ & $\begin{array}{c}0.71 \\
(0.45)\end{array}$ & $\begin{array}{c}0.68 \\
(0.47)\end{array}$ & $\begin{array}{c}0.70 \\
(0.46)\end{array}$ & $\begin{array}{c}0.72 \\
(0.45)\end{array}$ \\
\hline Black & $\begin{array}{c}0.27 \\
(0.44)\end{array}$ & $\begin{array}{c}0.24 \\
(0.43)\end{array}$ & $\begin{array}{c}0.24 \\
(0.42)\end{array}$ & $\begin{array}{c}0.25 \\
(0.43)\end{array}$ & $\begin{array}{c}0.24 \\
(0.43)\end{array}$ & $\begin{array}{c}0.23 \\
(0.42)\end{array}$ \\
\hline Other Race & $\begin{array}{c}0.06 \\
(0.24)\end{array}$ & $\begin{array}{c}0.05 \\
(0.23)\end{array}$ & $\begin{array}{c}0.05 \\
(0.21)\end{array}$ & $\begin{array}{c}0.06 \\
(0.24)\end{array}$ & $\begin{array}{c}0.05 \\
(0.22)\end{array}$ & $\begin{array}{c}0.04 \\
(0.20)\end{array}$ \\
\hline Age & $\begin{array}{l}24.24 \\
(6.27)\end{array}$ & $\begin{array}{l}27.99 \\
(6.51)\end{array}$ & $\begin{array}{l}28.59 \\
(6.39)\end{array}$ & $\begin{array}{l}25.60 \\
(6.52)\end{array}$ & $\begin{array}{l}28.08 \\
(6.60)\end{array}$ & $\begin{array}{l}28.80 \\
(6.70)\end{array}$ \\
\hline Highest Grade & $\begin{array}{l}11.70 \\
(2.05)\end{array}$ & $\begin{array}{l}12.51 \\
(2.41)\end{array}$ & $\begin{array}{l}13.06 \\
(2.34)\end{array}$ & $\begin{array}{l}11.71 \\
(2.25)\end{array}$ & $\begin{array}{l}12.94 \\
(2.18)\end{array}$ & $\begin{array}{l}13.56 \\
(2.18)\end{array}$ \\
\hline Married & $\begin{array}{c}0.11 \\
(0.32)\end{array}$ & $\begin{array}{c}0.44 \\
(0.50)\end{array}$ & $\begin{array}{c}0.43 \\
(0.49)\end{array}$ & $\begin{array}{c}0.27 \\
(0.45)\end{array}$ & $\begin{array}{c}0.47 \\
(0.50)\end{array}$ & $\begin{array}{c}0.39 \\
(0.49)\end{array}$ \\
\hline Separated & $\begin{array}{c}0.02 \\
(0.13)\end{array}$ & $\begin{array}{c}0.03 \\
(0.17)\end{array}$ & $\begin{array}{c}0.03 \\
(0.17)\end{array}$ & $\begin{array}{c}0.04 \\
(0.19)\end{array}$ & $\begin{array}{c}0.04 \\
(0.21)\end{array}$ & $\begin{array}{c}0.05 \\
(0.20)\end{array}$ \\
\hline Divorced & $\begin{array}{c}0.03 \\
(0.16)\end{array}$ & $\begin{array}{c}0.06 \\
(0.24)\end{array}$ & $\begin{array}{c}0.07 \\
(0.26)\end{array}$ & $\begin{array}{c}0.04 \\
(0.20)\end{array}$ & $\begin{array}{c}0.10 \\
(0.30)\end{array}$ & $\begin{array}{c}0.12 \\
(0.32)\end{array}$ \\
\hline Widowed & $\begin{array}{c}8.79 \mathrm{e}-04 \\
(0.03)\end{array}$ & $\begin{array}{c}1.65 \mathrm{e}-03 \\
(0.04)\end{array}$ & $\begin{array}{c}6.94 \mathrm{e}-04 \\
(0.03)\end{array}$ & $\begin{array}{c}3.88 \mathrm{e}-03 \\
(0.06)\end{array}$ & $\begin{array}{c}\text { 4.63e-03 } \\
(0.07)\end{array}$ & $\begin{array}{c}\text { 7.39e-03 } \\
(0.09)\end{array}$ \\
\hline Never Married & $\begin{array}{c}0.36 \\
(0.48)\end{array}$ & $\begin{array}{c}0.47 \\
(0.50)\end{array}$ & $\begin{array}{c}0.47 \\
(0.50)\end{array}$ & $\begin{array}{c}0.28 \\
(0.45)\end{array}$ & $\begin{array}{c}0.39 \\
(0.49)\end{array}$ & $\begin{array}{c}0.45 \\
(0.50)\end{array}$ \\
\hline Young Children & $\begin{array}{c}0.07 \\
(0.26)\end{array}$ & $\begin{array}{c}0.26 \\
(0.44)\end{array}$ & $\begin{array}{c}0.24 \\
(0.43)\end{array}$ & $\begin{array}{c}0.30 \\
(0.46)\end{array}$ & $\begin{array}{c}0.30 \\
(0.46)\end{array}$ & $\begin{array}{c}0.21 \\
(0.41)\end{array}$ \\
\hline No. of Children & $\begin{array}{c}0.35 \\
(0.84)\end{array}$ & $\begin{array}{c}0.68 \\
(1.07)\end{array}$ & $\begin{array}{c}0.68 \\
(1.08)\end{array}$ & $\begin{array}{c}1.26 \\
(1.30)\end{array}$ & $\begin{array}{c}0.93 \\
(1.11)\end{array}$ & $\begin{array}{c}0.83 \\
(1.13)\end{array}$ \\
\hline Health Limitations & $\begin{array}{c}0.06 \\
(0.24)\end{array}$ & $\begin{array}{c}0.03 \\
(0.18)\end{array}$ & $\begin{array}{c}0.03 \\
(0.18)\end{array}$ & $\begin{array}{c}0.08 \\
(0.26)\end{array}$ & $\begin{array}{c}0.05 \\
(0.21)\end{array}$ & $\begin{array}{c}0.05 \\
(0.22)\end{array}$ \\
\hline Previous Year Non-labor Income & $\begin{array}{c}14625.3 \\
(24751.47)\end{array}$ & $\begin{array}{c}12811.14 \\
(39459.02)\end{array}$ & $\begin{array}{c}13245.89 \\
(40488.66)\end{array}$ & $\begin{array}{c}18007.63 \\
(38969.35)\end{array}$ & $\begin{array}{c}17039.21 \\
(39039.21)\end{array}$ & $\begin{array}{c}16760.02 \\
(37454.45)\end{array}$ \\
\hline Mother Worked & $\begin{array}{c}0.59 \\
(0.49)\end{array}$ & $\begin{array}{c}0.61 \\
(0.49)\end{array}$ & $\begin{array}{c}0.64 \\
(0.48)\end{array}$ & $\begin{array}{c}0.57 \\
(0.49)\end{array}$ & $\begin{array}{c}0.64 \\
(0.48)\end{array}$ & $\begin{array}{c}0.68 \\
(0.47)\end{array}$ \\
\hline Father's Educational Attainment & $\begin{array}{l}10.92 \\
(3.86)\end{array}$ & $\begin{array}{l}10.99 \\
(4.00)\end{array}$ & $\begin{array}{l}11.62 \\
(3.81)\end{array}$ & $\begin{array}{l}10.57 \\
(4.00)\end{array}$ & $\begin{array}{l}11.08 \\
(3.84)\end{array}$ & $\begin{array}{l}11.84 \\
(3.78)\end{array}$ \\
\hline Mother's Educational Attainment & $\begin{array}{l}10.90 \\
(3.09)\end{array}$ & $\begin{array}{l}10.91 \\
(3.25)\end{array}$ & $\begin{array}{l}11.43 \\
(3.18)\end{array}$ & $\begin{array}{l}10.53 \\
(3.23)\end{array}$ & $\begin{array}{l}10.97 \\
(3.08)\end{array}$ & $\begin{array}{l}11.60 \\
(2.94)\end{array}$ \\
\hline Urban & $\begin{array}{c}0.79 \\
(0.41)\end{array}$ & $\begin{array}{c}0.79 \\
(0.41)\end{array}$ & $\begin{array}{c}0.81 \\
(0.40)\end{array}$ & $\begin{array}{c}0.77 \\
(0.43)\end{array}$ & $\begin{array}{c}0.80 \\
(0.41)\end{array}$ & $\begin{array}{c}0.81 \\
(0.40)\end{array}$ \\
\hline SMSA & $\begin{array}{c}1.53 \\
(1.11)\end{array}$ & $\begin{array}{c}1.47 \\
(1.02)\end{array}$ & $\begin{array}{c}1.47 \\
(0.99)\end{array}$ & $\begin{array}{c}1.46 \\
(1.08)\end{array}$ & $\begin{array}{c}1.49 \\
(1.00)\end{array}$ & $\begin{array}{c}1.50 \\
(0.97)\end{array}$ \\
\hline Northeast & $\begin{array}{c}0.10 \\
(0.30)\end{array}$ & $\begin{array}{c}0.18 \\
(0.38)\end{array}$ & $\begin{array}{c}0.19 \\
(0.39)\end{array}$ & $\begin{array}{c}0.11 \\
(0.31)\end{array}$ & $\begin{array}{c}0.18 \\
(0.38)\end{array}$ & $\begin{array}{c}0.20 \\
(0.40)\end{array}$ \\
\hline North Central & $\begin{array}{c}0.10 \\
(0.30)\end{array}$ & $\begin{array}{c}0.24 \\
(0.42)\end{array}$ & $\begin{array}{c}0.27 \\
(0.45)\end{array}$ & $\begin{array}{c}0.14 \\
(0.35)\end{array}$ & $\begin{array}{c}0.23 \\
(0.42)\end{array}$ & $\begin{array}{c}0.26 \\
(0.44)\end{array}$ \\
\hline South & $\begin{array}{c}0.19 \\
(0.39)\end{array}$ & $\begin{array}{c}0.38 \\
(0.49)\end{array}$ & $\begin{array}{c}0.33 \\
(0.47)\end{array}$ & $\begin{array}{c}0.25 \\
(0.43)\end{array}$ & $\begin{array}{c}0.40 \\
(0.49)\end{array}$ & $\begin{array}{c}0.36 \\
(0.48)\end{array}$ \\
\hline West & $\begin{array}{c}0.11 \\
(0.31)\end{array}$ & $\begin{array}{c}0.20 \\
(0.40)\end{array}$ & $\begin{array}{c}0.20 \\
(0.40)\end{array}$ & $\begin{array}{c}0.13 \\
(0.33)\end{array}$ & $\begin{array}{c}0.19 \\
(0.39)\end{array}$ & $\begin{array}{c}0.18 \\
(0.38)\end{array}$ \\
\hline Unemployment Rate & $\begin{array}{c}6.58 \\
(1.45)\end{array}$ & $\begin{array}{c}6.56 \\
(1.41)\end{array}$ & $\begin{array}{c}6.49 \\
(1.41)\end{array}$ & $\begin{array}{c}6.57 \\
(1.43)\end{array}$ & $\begin{array}{c}6.56 \\
(1.42)\end{array}$ & $\begin{array}{c}6.46 \\
(1.43)\end{array}$ \\
\hline
\end{tabular}


Appendix Table - Continued

\begin{tabular}{|c|c|c|c|c|c|c|}
\hline \multirow{2}{*}{ Variables } & \multicolumn{3}{|c|}{ Women } & \multicolumn{3}{|c|}{ Men } \\
\hline & No Job & One Job & Moonlighter & No Job & One Job & Moonlighter \\
\hline \multicolumn{7}{|l|}{ Primary Job Characteristics } \\
\hline Hourly Wage Rate & - & $\begin{array}{c}12.28 \\
(296.72)\end{array}$ & $\begin{array}{c}8.02 \\
(14.00)\end{array}$ & - & $\begin{array}{c}6.02 \\
(8.74)\end{array}$ & $\begin{array}{c}6.80 \\
(10.72)\end{array}$ \\
\hline Tenure & - & $\begin{array}{c}35.58 \\
(66.37)\end{array}$ & $\begin{array}{c}57.52 \\
(85.67)\end{array}$ & - & $\begin{array}{c}34.97 \\
(35.89)\end{array}$ & $\begin{array}{c}56.51 \\
(68.32)\end{array}$ \\
\hline Public Sector & - & $\begin{array}{c}0.08 \\
(0.27)\end{array}$ & $\begin{array}{c}0.15 \\
(0.36)\end{array}$ & - & $\begin{array}{c}0.14 \\
(0.35)\end{array}$ & $\begin{array}{c}0.18 \\
(0.38)\end{array}$ \\
\hline Private Sector & - & $\begin{array}{c}0.83 \\
(0.37)\end{array}$ & $\begin{array}{c}0.73 \\
(0.44)\end{array}$ & - & $\begin{array}{c}0.81 \\
(0.39)\end{array}$ & $\begin{array}{c}0.74 \\
(0.44)\end{array}$ \\
\hline Unpaid & - & $\begin{array}{c}2.85 \mathrm{e}-03 \\
(0.05)\end{array}$ & $\begin{array}{c}0.01 \\
(0.08)\end{array}$ & - & $\begin{array}{c}3.49 \mathrm{e}-03 \\
(0.06)\end{array}$ & $\begin{array}{c}6.87 \mathrm{e}-03 \\
(0.08)\end{array}$ \\
\hline Professionals, Technicians, Clerical & - & $\begin{array}{c}0.26 \\
(0.44)\end{array}$ & $\begin{array}{c}0.36 \\
(0.48)\end{array}$ & - & $\begin{array}{c}0.55 \\
(0.50)\end{array}$ & $\begin{array}{c}0.61 \\
(0.49)\end{array}$ \\
\hline Craftsmen, Operators, Laborers & - & $\begin{array}{c}0.52 \\
(0.50)\end{array}$ & $\begin{array}{c}0.39 \\
(0.49)\end{array}$ & - & $\begin{array}{c}0.13 \\
(0.33)\end{array}$ & $\begin{array}{c}0.11 \\
(0.31)\end{array}$ \\
\hline Sales and Service Workers & - & $\begin{array}{c}0.19 \\
(0.39)\end{array}$ & $\begin{array}{c}0.22 \\
(0.41)\end{array}$ & - & $\begin{array}{c}0.29 \\
(0.45)\end{array}$ & $\begin{array}{c}0.25 \\
(0.43)\end{array}$ \\
\hline \multicolumn{7}{|l|}{ Secondary Job Characteristics } \\
\hline Hours Worked & - & - & $\begin{array}{c}30.21 \\
(25.30)\end{array}$ & - & - & $\begin{array}{c}25.47 \\
(22.08)\end{array}$ \\
\hline
\end{tabular}

